\title{
Effects of cerebral gymnastics in cognition and subjective welfare of institutionalized elderly people
}

\author{
Efeitos da ginástica cerebral na cognição e no \\ bem-estar subjetivo de idosas institucionalizadas
}

\section{Efectos de la gimnastica cerebral en la cognición y en el bienestar subjetivo de las personas ancianas institucionalizadas}

\author{
Carlos Eduardo Viana Santos ${ }^{\circledR[a]}$, Alex de Oliveira Ribeiro $₫[b]$, \\ Luciana Crepaldi Lunkes $\left.{ }^{[a}\right]^{*}$ \\ [a] Centro Universitário de Lavras (UNILAVRAS), Lavras, MG, Brazil \\ [b] Universidade Federal de Lavras (UFLA), Lavras, MG, Brazil
}

\section{Abstract}

Introduction: With the increasing number of elderly people, greater care is required for this population, and zeal for health and quality of life becomes an important goal in healthy aging. Elderly people can achieve excellent results involving cognitive training based on brain plasticity. Objective: To verify the effectiveness of cerebral gymnastics in the cognitive state and well-being of institutionalized elderly women. Method: Clinical trial performed with nine institutionalized elderly women, mean age of 80.2 years old $( \pm 9.1)$. The Subjective Well-being Scale and tests (clock, verbal fluency, figure recognition) were administered before and after ten weeks of the exercise program (eight exercises performed in two

\footnotetext{
* CEVS: undergraduate student, e-mail: carlos.viana.96@outlook.com AOR: PhD, e-mail: alexribeiro@uai.com.br LCL: PhD, e-mail: lucianaclunkes@gmail.com
} 
weekly meetings, involving figures, words and objects). The data normality was verified using the ShapiroWilk test, followed by Student $t$ tests for analysis of SWB and Wilcoxon for analysis of figure recognition, clock-drawing test and verbal fluency. Results: Significant improvement in the incidental and immediate memory 1 and 2 ( $p=0.007)$, verbal fluency ( $p=0.011, p=0.025$ and $p=0.007)$ and the clock-drawing test ( $p$ value $=0.046)$. No significant results were found for SWB $(p=0.357$ and $p=0.389)$. Conclusion: Brain gymnastics beneficially modified cognitive performance. Well-being did not show significant improvements.

Keywords: Aging. Neuronal Plasticity. Exercise. Memory. Quality of life.

\section{Resumo}

Introdução: Com o crescente número de idosos faz-se necessário maior cuidado com essa população, onde o zelo com a saúde e qualidade de vida tornam-se metas importantes no envelhecimento saudável. Os idosos possuem competência para atingir excelentes resultados envolvendo treino cognitivo pela plasticidade cerebral. Objetivo: Verificar a eficácia da ginástica cerebral no estado cognitivo e no bem-estar de idosas institucionalizadas. Método: Ensaio clínico realizado com nove idosas institucionalizadas, com média de idade de 80,2 anos $( \pm$ 9,1). Foram utilizados a Escala de Bem-Estar Subjetivo e testes (relógio; fluência verbal; reconhecimento de figuras), aplicados antes e após dez semanas do programa de exercícios (Oito exercícios realizados em dois encontros semanais, envolvendo figuras, palavras e objetos). A normalidade dos dados foi verificada pelo teste de Shapiro-Wilk, seguido pelos testes $t$ de Student para análise da EBES e Wilcoxon para análises do reconhecimento de figuras, teste do relógio e fluência verbal. Resultados: Melhora significativa da memória incidental e imediata 1 e 2 ( $p=0.007)$, da fluência verbal $(p=0,011 ; p=0,025$ e $p=0,007)$ $e$ do teste do relógio ( $p$ valor $=0,046)$. Resultados não significativos para EBES $(p=0,357$ e $p=0,389)$. Conclusão: A ginástica cerebral modificou beneficamente o desempenho cognitivo. O bem-estar não apresentou melhoras significativas.

Palavras-chave: Envelhecimento. Plasticidade Neuronal. Exercício. Memória. Qualidade de Vida.

\section{Resumen}

Introducción: Con el creciente número de ancianos se hace necesario mayor cuidado con esa población, donde el celo con la salud y calidad de vida se convierten en metas importantes en el envejecimiento saludable. Los ancianos poseen competencia para alcanzar excelentes resultados involucrando entrenamiento cognitivo por la plasticidad cerebral. Objetivo: Verificar la eficacia de la gimnasia cerebral en el estado cognitivo y en el bienestar de ancianas institucionalizadas. Método: Ensayo clínico realizado con nueve ancianas institucionalizadas, con una media de edad de 80,2 años $( \pm 9,1)$. Se utilizó la Escala de Bienestar Subjetivo y pruebas (reloj, fluencia verbal, reconocimiento de figuras), aplicados antes y después de diez semanas del programa de ejercicios (Ocho ejercicios realizados en dos encuentros semanales, envolviendo figuras, palabras y objetos). La normalidad de los datos fue verificada por la prueba de Shapiro-Wilk, seguida por las pruebas t de Student para análisis de EBES y Wilcoxon para análisis del reconocimiento de figuras, prueba del reloj y fluencia verbal. Resultados: Mejora significativa de la memoria incidental e inmediata 1 y 2 ( $p=0.007)$, de la fluencia verbal ( $p=0,011 ; p=0,025$ y $p=0,007)$ y de la prueba del reloj ( $p$ valor $=0,046)$. Resultados no significativos para EBES ( $p=0,357$ y =0,389). Conclusión: La gimnasia cerebral modificó benéficamente el desempeño cognitivo. El bienestar no presentó mejoras significativas.

Palabras clave: Envejecimiento. Plasticidad Neuronal. Ejercicio. Memoria. Calidad de Vida. 


\section{Introduction}

During the aging process, many physical and psychological complications are associated with loss of mobility, muscular function and physiological functions related to the elderly cognitive condition along with degenerative processes. These alterations might result in reduction or loss of independence, physical and social performance, learning ability, direction, language, among others [1].

Many factors linked to aging favor the appearance of cognitive deficits. Therefore, memorization ability (storage, coding and retrieval) is harmed, considering that such parameters act unequally when comparing young and old people $[2,3]$.

For this reason, the institutionalization process might result in important alterations linked to functional and cognitive reductions, in addition to favoring the start of a depressive condition, mainly when comparing this group with that of socially active elders [4].

Therefore, cerebral stimulation using games seems to be an important factor to the neuronal plasticity, promoting increase in the brain activity in multiple cortical regions [5]. Neuronal plasticity occurs due to the increase in the interaction between cortical regions, promoting certain neural reorganization [6]. With the current demographic trend, the attention given to the elderly population is more and more evident in society, aiming at improving the quality of the support given to this group [7].

Research involving cognitive training indicates that old people are competent to achieve excellent results with cognitive stimuli and may reach the highest level possible, through the promotion of brain plasticity [8-10]. In this sense, regarding getting older, seeking quality of life defined as the existing interrelation between interior perception and exterior perception of the human being life is very important [11]. Getting older, along with the limitations that might affect such quality of life, should never be understood as a disease, but rather as a natural body process that requires care as any other [12].

Satisfaction with life involves many factors such as happiness, one's own control, noticeable health, lack of stress, social relationships, among others. Although these aspects vary among individuals, the construction of an ideal condition of quality of life is based on well-being and personal satisfaction, enabling continuous benefits to the elderly [13]. Thus, old people should seek to improve their quality of life through wellness, not facing the complications resulting from time as indestructible barriers, but rather as sources of new knowledge, possibilities of overcoming this phase that requires a lot of care.

However, the literature still has gaps regarding the evidence of efficacy of cerebral gymnastics in old people as well as regarding the best way to apply it. In this sense, cognitive training appears as an option to obtain visible response concerning satisfaction, wellness and improvement in the cognitive activity of institutionalized old people.

Considering that cerebral gymnastics might be vital for preserving memory through stimuli of the neural connections, this study aimed at verifying the efficacy of a program of cerebral gymnastics exercises in the cognitive and subjective well-being of institutionalized elderly women.

\section{Methods}

This is a clinical trial carried out in a longpermanence institution for old people (LPI) that shelters exclusively old women, located in the city of Oliveira, Minas Gerais, Brazil.

The research project was submitted to and approved by the Research Ethics Committee (CEP) of the Lavras University Center (CAAE 51261115.0.0000.5116; Opinion Number 1.346.617). The final sample comprised nine residents with average age of 80.2 years old (9.1). The volunteers followed criteria that included: female elderly, residing in LPI, aged 60 years old or over and with good eyesight and hearing condition. Any old woman would be excluded if she did not attend at least $90 \%$ of the sessions, developed other exercises during the program proposed, presented Alzheimer disease or any other dementia, or any other disease that could hamper the development of the exercise program for cerebral stimulus, or those who opted to drop at any moment. During the development of the activities, no elimination was needed. Based on the total of elderlies living in that LPI, all those who decided to participate and agreed with the inclusion criteria were selected.

The following instruments were used in the data collection: a questionnaire devised by the authors including questions referring to age, time of stay in the institution, schooling (incomplete elementary school, 
incomplete or complete high school, incomplete or complete higher education), retirement, monthly income (considering the reference value of the national minimum wage, $\mathrm{R} \$ 880.00$ - up to two minimum wages, up to six minimum wages or over six minimum wages), smoking (whether a smoker or not), presence of a pathological condition, marital status (with or without a partner), and frequency of physical exercise practice and/or leisure activity (less than three times a week, at least three times a week or none/never); a questionnaire to evaluate subjective well-being (SWB), containing items (words and questions) linked to positive and negative affection characterized by the respondent through a score (from 1, not a bit; to 5, extremely), which rated the relevant item [14]; Clock-drawing test (CDT), in which a circle drawn was previously offered to the volunteer and she was then asked to complete the drawing forming a clock that showed the time "11:10" [15]; Verbal fluency test (VFT) in which the volunteers were asked to say the most words they could beginning with the letters $\mathrm{A}, \mathrm{S}$ and F, other than animals or fruit, during the maximum time of one minute preset for each letter or word [16]; Figure recognition test (FRT), in which a sequence of figures was shown and withdrawn after a certain period, and later on the volunteers were asked to remember the images immediately after the latter were removed (incidental memory). The image was shown again for 30 seconds, and the process was repeated (immediate memory I), the process was then repeated just as in the immediate memory 1 phase and characterized as immediate memory 2 and five minutes later, the volunteers were asked to remember the figures again without seeing them [17].

An initial session took place in a proper place previously determined by the institution. In this session, the anamnesis questionnaires SWB, CDT, VFT and FRT were administered and the exercise program was explained. The sessions were carried out twice a week, for 32 minutes, on days and at times mutually agreed upon and considering the availability of the elderly women, respecting the institutional activities. Table 1 shows the exercise program used in all sessions, which were gradually altered regarding their level of difficulty (reduction in execution time, larger number of words, figures or colors to be memorized, described or differentiated, respectively, and a wider variety of objects to be touched, described and remembered, in which the average time for the accomplishment of each task proposed was four minutes. After ten weeks ( 20 sessions), a final session for reassessment took place, in which all the tests were repeated. The evaluations were carried out by two examiners who had been previously trained and who were blinded to avoid interference in the tests. One examiner was in charge of the initial and final evaluations, and the other of the activities proposed in the exercise program.

The results of figure recognition, clock-drawing and oral fluency tests are presented in points (ordinal scale) and, therefore, do not follow a norm. Also, the Wilcoxon test at $5 \%$ probability was used to evaluate the data of the variables visual perception, correct naming, incidental memory, immediate memory and figure recognition (Table 2), as well as the clockdrawing test (Table 3 ) and the variables animals, fruit, F, A and S of the oral fluency test (Table 4).

Regarding the subjective well-being scale (SWB), as the result involves means, the Shapiro-Wilk test at $5 \%$ level of significance was used, confirming the data normality. The Student $t$ test was used, not showing significance regarding positive $(\mathrm{p}=0.357)$ or negative $(p=0.389)$ affection (Table 5).

Table 1 - Cerebral gymnastics exercise program

\begin{tabular}{ll}
\hline EXERCISE PROGRAM & $\begin{array}{l}\text { Identical figures distributed in pairs, in which the old woman should turn one figure at a time, trying to find the } \\
\text { identical pairs }\end{array}$ \\
\hline Duration: 10 weeks (2 sessions / week) & $\begin{array}{l}\text { Several figures were observed and memorized at different times; after that the old woman should count the } \\
\text { figures she could remember, also at different times. } \\
\text { Figure memorization }\end{array}$ \\
Differentiation of colors & $\begin{array}{l}\text { Wooden circles of different colors were handed out, and the old woman was asked to put each color on the } \\
\text { respective place marked with the relevant colors. }\end{array}$
\end{tabular}

(To be continued) 
(Conclusion)

\begin{tabular}{ll}
\hline EXERCISE PROGRAM & \\
\hline Duration: 10 weeks (2 sessions / week) \\
\hline Description of sayings & $\begin{array}{l}\text { Several Brazilian popular sayings were cited, such as "água mole em pedra dura, tanto bate até que fura" } \\
\text { (something like: constant dropping wears away a stone"), and the old woman was asked to explain their real } \\
\text { meaning. } \\
\text { The old woman was asked to write or say a shopping list and describe the greatest number of objects existing } \\
\text { in the room where she was. }\end{array}$ \\
Executive function & $\begin{array}{l}\text { The old woman should look for letters F in a short text; for illiterate participants the 'figure F' was sought. } \\
\text { F test }\end{array}$ \\
$\begin{array}{l}\text { The old woman was asked to name several different figures and read words backwards, texts containing } \\
\text { numbers in between the letters, texts with words with scrambled letters. Illiterate participants were asked to } \\
\text { find figures. }\end{array}$ \\
$\begin{array}{l}\text { The old woman was asked, whenever possible, to write her name and/or produce a drawing with her left hand } \\
\text { (if she was right-handed) or with her right hand (if she was left-handed). } \\
\text { sensorial interpretation) }\end{array}$
\end{tabular}

\section{Results}

Regarding schooling, four old women had not completed elementary school, one of the participants had not completed high school and four of them had never studied. They were all retired, with an average monthly income of up to two minimum wages. Two of the residents smoked. None of the them had a partner, four of them were single and five were widows. They were exposed to physical exercises and leisure activities less than three times a week, in routine activities at the institution such as stretching, short walks and/or manual labor linked to handcrafting.

Table 2 shows the Wilcoxon test results with significant values for incidental, immediate and immediate 2 memory $(\mathrm{p}=0,007)$.

Table 2 - Initial and final comparison of the final score of the figure recognition test through the Wilcoxon test at $5 \%$ significance.

\begin{tabular}{lccc}
\hline Variables & Period & Mean & p value \\
\hline \multirow{2}{*}{ Visual Perception } & Initial & 7.89 & \multirow{2}{*}{0.680} \\
& Final & 8.22 & \\
\hline \multirow{2}{*}{ Correct naming } & Initial & 7.89 & \multirow{2}{*}{0.414} \\
& Final & 8.11 & \\
\hline \multirow{2}{*}{ Incidental Memory } & Initial & 3.22 & \multirow{2}{*}{$0.007^{\star}$} \\
\hline \multirow{2}{*}{ Immediate Memory } & Final & 5.78 & \\
& Initial & 5.00 & \multirow{2}{*}{$0.007^{\star}$} \\
\hline \multirow{2}{*}{ Immediate Memory 2 } & Final & 6.78 & \\
& Initial & 4.56 & \multirow{2}{*}{$0.007^{\star}$} \\
\hline \multirow{2}{*}{ Five Minutes } & Final & 7.11 & \\
\hline
\end{tabular}

Note: *Wilcoxon Text, significant at 5\% probability.

Table 3 shows the results of the residents' cognition $(p=0.046)$. Four old women were seen to increase one point in their results in the second assessment of the clock-drawing test, after carrying out cerebral gymnastics exercises. In general, they went from a mean value of 1.67 in the initial evaluation to 2.11 in the final one.

Table 3 - Initial and final comparison of the clock-drawing test through the Wilcoxon test at $5 \%$ significance.

\begin{tabular}{lccc}
\hline Variable & Period & Mean & p value \\
\hline \multirow{2}{*}{ Clock-drawing test } & Initial & 1.67 & \multirow{2}{*}{$0.046^{*}$} \\
& Final & 2.11 & \\
\hline
\end{tabular}

Note: *Wilcoxon test, significant at $5 \%$ probability.

Table 4 shows the results of semantic memory and verbal fluency revealing significant value for animals ( $p=0.011)$, variables $F(p=0.011), A(p=0.025)$ and $S(p=0.007)$. The variable fruit did not show a significant value $(\mathrm{p}=0.944)$.

Table 4 - Initial and final comparison of the verbal fluency test through the Wilcoxon test at $5 \%$ level of significance.

\begin{tabular}{lccc}
\hline Variables & Period & Mean & p value \\
\hline \multirow{2}{*}{ Animals } & Initial & 8.56 & \multirow{2}{*}{$0.011^{\star}$} \\
& Final & 12.00 & \\
\hline \multirow{2}{*}{ Fruit } & Initial & 8.89 & \multirow{2}{*}{0.944} \\
& Final & 8.78 & \\
\hline \multirow{2}{*}{ F } & Initial & 3.44 & \multirow{2}{*}{$0.011^{\star}$} \\
\hline \multirow{2}{*}{ A } & Final & 6.33 & \\
& Initial & 2.78 & \multirow{2}{*}{$0.025^{\star}$} \\
S & Final & 4.78 & \\
& Initial & 2.56 & \multirow{2}{*}{$0.007^{\star}$} \\
\hline
\end{tabular}

Note: *Wilcoxon test, significant at 5\% probability. F; A, S: Initials used in the verbal fluency test, in which the participant was asked to say the greatest number of words she could starting with each letter in one minute. 
Table 5 shows the Student $\mathrm{t}$ test associated with wellness, in which the values were not significant.

Table 5 - Initial and final comparison of the Well-being Scale (SWB) through the Student $t$ test at $5 \%$ level of significance.

\begin{tabular}{|c|c|c|c|c|}
\hline \multirow[b]{2}{*}{ Variables } & \multirow[b]{2}{*}{ Period } & \multicolumn{2}{|c|}{ Descriptive statistics } & \multirow[b]{2}{*}{$\mathrm{p}$ value } \\
\hline & & Mean & $\begin{array}{l}\text { Standard } \\
\text { deviation }\end{array}$ & \\
\hline \multirow{2}{*}{$\begin{array}{l}\text { Positive } \\
\text { affection }\end{array}$} & Initial & 3.386 & 0.576 & \multirow{2}{*}{0.357} \\
\hline & Final & 3.444 & 0.836 & \\
\hline $\begin{array}{l}\text { Negative } \\
\text { affection }\end{array}$ & $\begin{array}{l}\text { Initial } \\
\text { Final }\end{array}$ & $\begin{array}{l}2.840 \\
2.790\end{array}$ & $\begin{array}{l}0.826 \\
1.043\end{array}$ & 0.389 \\
\hline
\end{tabular}

\section{Discussion}

This study highlights significantly positive alterations in the cognitive condition of institutionalized old women submitted to a program of cerebral gymnastics exercises (short-term cerebral stimulation).

The results obtained through the CDT were not significant $(2,11)$, but the percentage increased significantly when comparing the first and second cognitive assessments (79.15\%). A study developed by Lima evaluated 20 old people aging $50.6( \pm 14,7)$ years. Among these people, 31 were women and seven were men. They all showed depression symptoms and were taking medicine. Initially, the CDT presented the mean score of $5.2( \pm 3)$ points, but after the pharmacological treatment, only $31.6 \%$ obtained normal performance, with the mean score of $3.5( \pm 1,6)$ points [18]. In this study, in which the average age was 80.2 years old, which is considered higher than the mean in the study above, $44 \%$ of the elderly women evaluated reacted positively to the exercises. This result suggests cognitive stimulation. Also, $56 \%$ of the volunteers kept the same initial levels, and no decline was observed when comparing the first and second evaluations. Another study was developed with 65 old people, 40 women and 25 men, whose average age was 80 years old. These authors observed the clock-drawing test showed a general mean of 4.50 points, characterized as low for the age range under study [19]. Another study reported that the CDT showed an average of 5.98 points in a Chinese population whose average age was 78.6 years old [20].
Regarding the VFT, the old women showed improvement in relation to memory, and four out of five variables had significant alterations (Animals, Fruit, F, A and S). During the test, the volunteers were stimulated to analyze the words they knew and relate them to the letters shown. This enabled analyses of the variable time associated with the test, since, when the time for the answer was limited, the participants directed their thoughts faster and more intensely to what had been asked, which resulted in more interaction with the activity carried out, favoring good results. Lima also pointed out positive changes linked to the test, in which the individuals who did not present alterations at least kept their levels [18].

In relation to $S W B$, no statistically significant results were found. This result was ascribed to the daily interaction between the residents, which was many times hampered by their psychological state, along with family distancing, the hope to be reunited with the family or go back to their family's home. Also, limitations imposed by age that made the residents show certain nervousness and dissatisfaction might have led to these results.

It seems relevant to consider that the daily interaction in elderly people's homes might generate social discomfort (or not), as mentioned in a study that similarly used SWB to evaluate old people aged between 60 and 82 years old, comprising 29 (74.4\%) women and 10 (25.6\%) men. Those authors observed the social impact on the subjective well-being and functionality of 39 old people in that community in Uberaba, MG, where a greater number of people residing in the same local as the old person under evaluation increased the data referring to negative affection. However, those results were not significant either [21].Several aspects of old age have been under evaluation, health areas have pointed out the existing interrelation between quality of life, functionality and well-being in relation to a harmonious social structure [22]. It also seems important to highlight in the literature the relation between reduction in functionality and well-being and the reduction in social support to the elderly [23, 24]. Social support has been defined as the group of individuals from whom old people receive some help, either material, affective or mental [25]. This attitude is observed mutually in another study in which the generation of positive affection led to a greater meaning to life, both for the helper and for the one in need of help $[26,27]$. Discomfort reduction can be observed in the 
social daily interaction, since its limitations might have positive results in different individuals [28, 29].

The results obtained from the FRT showed relevant data are linked to the incidental and immediate 1 and 2 memories, demonstrating that the use of cerebral gymnastics promoted positive evolution. A study on the audio efficacy of the performance of cognitive functions of old people's memory and attention showed the values found in a population aged 60 years old or over were high (close to 10), revealing good cognitive response. That author emphasizes the importance of visual stimulus for the memorization process, mainly linked to recognition [30]. However, such fact was not significant in this study, in which the significance values confirmed beneficial alterations directly related to the memory of the institutionalized old women, evidencing the efficacy of the methods used for incidental memory, immediate 1 (images shown for memorization for 30 seconds, and later on retrieved, asking the description of the content seen) and immediate 2 (repetition of the procedure described for immediate 1 memory). The limitations of this study include lack of control over some of the old women's difficulties to socialize on certain occasions, which resulted in socioenvironmental discomfort, family distancing and feeling of abandonment, which might have influenced the results regarding well-being.

\section{Conclusion}

The cerebral gymnastics program for institutionalized old women was effective in improving their cognitive development, enabling better performance of the incidental and immediate memory and verbal fluency through cognitive stimulation. Regarding subjective well-being, although the residents had demonstrated satisfaction during the activities, the results obtained were not significant enough to promote improvements.

Carrying out a program of cerebral gymnastics in institutionalized people is recommended, so that they can enjoy its benefits to their quality of life. Further studies are also recommended including different sample groups.

\section{Acknowledgments}

The author is thankful to the participants of this study for being so welcoming and available, making the development of the research possible. To the Centro Universitário de Lavras -UNILAVRAS (University Center of Lavras) for the reception and support to the research and to the Fundação de Apoio à Pesquisa de Minas Gerais (FAPEMIG) (Research Support Foundation) for believing in the students willing to contribute to science and making the necessary support available.

\section{References}

1. Leite MT, Castioni D, Kirchner RM, Hildebrandt LM. Capacidade funcional e nível cognitivo de idosos residentes em uma comunidade do Sul do Brasil. Enferm Glob. 2015;14(37):12-22.

2. Kausler DH. Experimental psychology, cognition, and human aging. 2nd ed. New York: Springer-Verlag; 1991.

3. Salthouse TA. Theoretical perspectives on cognitive aging. Hillsdale (NJ): Erlbaum; 1991.

4. Trindade APNT, Barboza MA, Oliveira FB, Borges APO. Repercussão do declínio cognitivo na capacidade funcional em idosos institucionalizados e não institucionalizados. Fisioter Mov. 2013;26(2):281-9.

5. Pessini RA, Reis RM, César HV, Gamez L. Análise da plasticidade neuronal com o uso de jogos eletrônicos. J Health Inform. 2018;10(1):25-9.

6. Filippo TRM, Alfieri FM, Cichon FR, Imamura M, Battistella LR. Neuroplasticidade e recuperação funcional na reabilitação pós-acidente vascular encefálico. Acta Fisiatr. 2015;22(2):93-6.

7. Silva GGP, Oliveira TS, Maia LFS. Saúde do idoso: abordagem da literatura sobre a segurança do paciente. Rev Recien. 2018;8(22):64-75.

8. Verhaeghen P. The interplay of growth and decline: theoretical and empirical aspects of plasticity of intellectual and memory performance in normal old age. In: Hill RD, Backman L, Stigsdotter-Neely A, editors. Cognitive rehabilitation in old age. New York: Oxford University Press; 2000. p. 3-22.

9. Backman L. Varieties of memory compensation by older adults in episodic remembering. In: Poon L, Rubin D, Wilson B, editors. Everyday cognition in adulthood and late life. Cambridge (UK): Cambridge University Press; 1989. p. 509-54. 
10. Yassuda MS, Batistoni SST, Fortes AG, Neri AL. Treino de memória no idoso saudável: benefícios e mecanismos. Psicol Reflex Crit. 2006;19(3):470-81.

11. Browne JP, O’Boyle CA, McGee HM, Joyce CRB, McDonald NJ, O'Malley K, et al. Individual quality of life in the healthy elderly. Qual Life Res. 1994;3(4):235-44.

12. Lima DL, Lima MAD, Ribeiro CG. Envelhecimento e qualidade de vida de idosos institucionalizados. RBCEH. 2010;7(3):346-56.

13. Sposito G, D’Elboux MJ, Neri AL, Guariento ME. A satisfação com a vida e a funcionalidade em idosos atendidos em um ambulatório de geriatria. Cienc Saude Coletiva. 2013;18(12):3475-82.

14. Albuquerque AS, Tróccoli BT. Desenvolvimento de uma escala de bem-estar subjetivo. Psicol Teor Pesqui. 2004;20(2):153-64.

15. Critchley M. The parietal lobes. Oxford: Williams and Wilkins; 1953.

16. Spreen O, Strauss E. A compendium of neuropsychological tests: administration, norms, and commentary. 2nd ed. New York: Oxford University Press; 1998.

17. Nitrini R, Lefèvre BH, Mathias SC, Caramelli P, Carrilho PEM, Sauaia N, et al. Testes neuropsicológicos de aplicação simples para diagnóstico de demência. Arq Neuropsiquiatr. 1994;52(4):457-65.

18. Lima MBS. Disfunção cognitiva na depressão maior antes e após tratamento farmacológico, em pacientes acompanhados em hospital de referência em Salvador Bahia Brasil [undergraduate dissertation]. Salvador: Universidade Federal da Bahia; 2015.

19. Schmidt JA, Dal-Pizzol F, Xavier FMF, Heluany CCV. Aplicação do teste do relógio em octogenários e nonagenários participantes de estudo realizado em Siderópolis/SC. Psico. 2009;40(4):525-30.

20. Chan CC, Yung CY, Pan PC. Screening of dementia in Chinese elderly adults by the clock drawing test and the time and change test. Hong Kong Med J. 2005;11(1):13-9.

21. Dutra FCMS, Silva HRO. Bem-estar subjetivo, funcionalidade e apoio social em idosos da comunidade. Estud Interdiscip Envelhec. 2014;19(3):775-91.
22. Rosa TEC, Benício MHD, Alves MCGP, Lebrão ML. Aspectos estruturais e funcionais do apoio social de idosos do município de São Paulo, Brasil. Cad Saude Publica. 2007;23(12):2982-92.

23. Carneiro RS, Falcone E, Clark C, Prette ZD, Prette AD. Qualidade de vida, apoio social e depressão em idosos: relação com habilidades sociais. Psicol Reflex Crit. 2007;20(2):229-37.

24. Alvarenga MRM, Oliveira MAC, Domingues MAR, Amendola F, Faccenda O. Rede de suporte social do idoso atendido por equipes de saúde da família. Cienc Saude Colet. 2011;16(5):2603-11.

25. Griep RH. Confiabilidade e validade de instrumentos de medida de rede social e de apoio social utilizados no estudo pró-saúde [dissertation]. Rio de Janeiro: Fundação Oswaldo Cruz; 2003.

26. Pedro ICS, Rocha SMM, Nascimento LC. Apoio e rede social em enfermagem familiar. Rev Latinoam Enferm. 2008;16(2):324-7.

27. Resende MC, Bones VM, Souza IS, Guimarães NK. Rede de relações sociais e satisfação com a vida de adultos e idosos. Psicol Am Lat. 2006;(5):1-20.

28. Ramos MP. Apoio social e saúde entre idosos. Sociologias. 2002;4(7):156-75.

29. Silva I, Pais-Ribeiro J, Cardoso H, Ramos H, Carvalhosa SF, Dias S, et al. Efeitos do apoio social na qualidade de vida, controle metabólico e desenvolvimento de complicações crônicas em indivíduos com diabetes. Psicol Saude Doenças. 2003;4(1):21-32.

30. Sacramento AM. Autoeficácia do desempenho das funções cognitivas de memória e atenção em idosos [dissertation]. Brasília (DF): Universidade Católica de Brasília; 2014.

Received on $11 / 04 / 2017$ Recebido em 04/11/2017 Recibido en 04/11/2017

Approved on $01 / 15 / 2019$ Aprovado em 15/01/2019 Aprobado en 15/01/2019 